\title{
RECURRENT GIANT-CELL TUMOUR AFTER EN BLOC EXCISION OF THE DISTAL RADIUS AND FIBULAR AUTOGRAFT REPLACEMENT
}

\author{
W. R. HARRIS, E. C. H. LEHMANN
}

\author{
From the Toronto General Hospital, Toronto, and St Paul's Hospital, Vancouver
}

\begin{abstract}
We report two patients, each with a giant-cell tumour of the distal radius treated by curettage and bone grafting. Local recurrence of the tumour occurred in the autograft and in the adjacent soft tissues in both patients, and was successfully treated by local excision; one patient also had radiation therapy. Both remain well 20 years and five years later.
\end{abstract}

Local recurrence of giant-cell tumour after curettage with or without bone grafting occurs in more than 50 per cent of patients (Goldenberg, Campbell and Bonfiglio 1970). In these circumstances en bloc excision and replacement with a massive autograft is the treatment of choice (Campbell and Akbarnia 1975; Smith and Mankin 1977). This paper reports two patients, each with giant-cell tumour of the distal radius, treated by this technique.

\section{ILLUSTRATIVE CASE HISTORIES}

Case 1. A 24-year-old woman, who was four months pregnant, presented with a painful swelling of her right wrist of two months' duration. Radiographs showed a lytic lesion typical of a giant-cell tumour in the distal radius (Fig. 1). Six weeks later a biopsy revealed a giantcell tumour of extreme cellularity and moderate mitotic activity. Because of the histological appearance and because the tumour was fungating through the biopsy wound, en bloc excision of the distal third of the radius and of an ellipse of skin and soft tissue at the site of biopsy was carried out; the proximal third of the ipsilateral fibula was used to replace the bone removed. No attempt was made to fuse the fibula to the carpus. The pathology report confirmed the presence of a giantcell tumour (Grade II) similar in appearance to the biopsy material.

When seen one year later she had a 50 per cent restriction of dorsiflexion and palmar flexion of the wrist but normal rotation of the forearm. Radiographs, while

W. R. Harris, MD, FRCS(C), Senior Surgeon

Division of Orthopaedic Surgery, Toronto General Hospital, 101 College Street, Toronto, Ontario M5G IL7, Canada.

E. C. H. Lehmann, MD, FRCS(C), Senior Surgeon

Division of Orthopaedic Surgery, St Paul's Hospital, 1144 Burrard St, Vancouver, British Columbia V6Z 2A5, Canada.

Requests for reprints should be sent to $\mathrm{Mr} \mathrm{W}$. $\mathrm{R}$. Harris.

(C) 1983 British Editorial Society of Bone and Joint Surgery $0301-620 \times / 83 / 5121 \$ 2.00$ showing that the fibular graft was united, revealed a lytic lesion two centimetres in diameter at the distal end of the graft (Fig. 2). This area was explored. There was loss of the anterior cortex of the graft at the site of the lesion which was filled with clot. This was curetted, cauterised

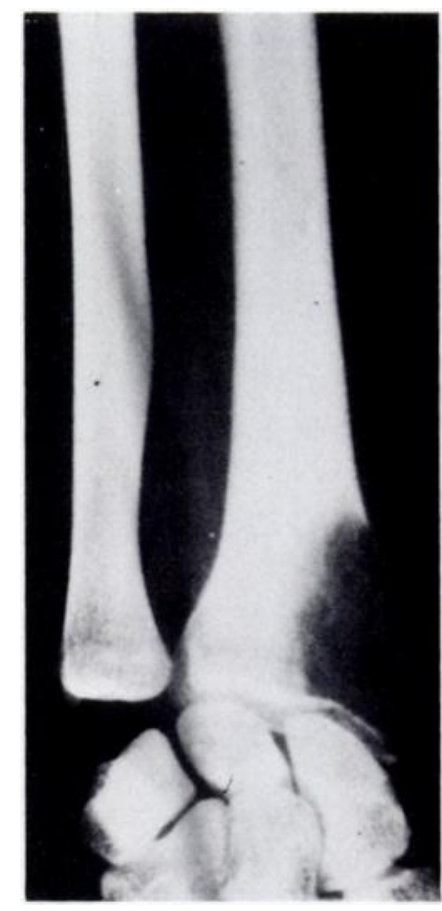

Fig. 1

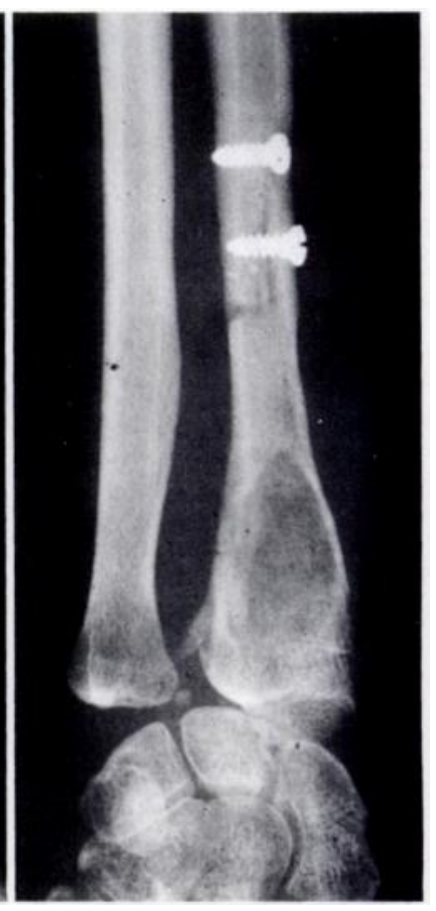

Fig. 2
Case 1. Figure 1-Radiographic appearance of the lower arm and wrist at the time of the original biopsy showing the lytic lesion in the distal radius. Figure 2-Radiograph taken one year after the fibular autograft showing the local recurrence of the giant-cell tumour.

with carbolic acid and alcohol, and packed with cancellous bone from the iliac crest. The pathologist's report was "residual giant-cell tumour (Grade II), similar in appearance to the previous material".

The patient was next seen six years later when, in a car accident, she fractured her right radius at its junction 
with the fibular graft. There was no evidence of recurrence of the tumour. Uneventful healing occurred after immobilisation in a plaster cast. She was last seen 20 years after the original operation; she remained free of recurrence and had satisfactory function of the wrist.

Case 2. A 24-year-old man presented with a six-week history of pain in the left wrist. Radiographs showed a lytic lesion consistent with a giant-cell tumour (Fig. 3). Treatment was by means of curettage. The histological report was a "giant-cell tumour (Grade II)". The lesion recurred and two months later was curetted and packed with cancellous bone from the iliac crest. The lesion continued to increase in size and two months later the distal third of the radius was removed en bloc and replaced with the upper end of the ipsilateral fibula, fixing the end of the fibula to the proximal row of the carpus.

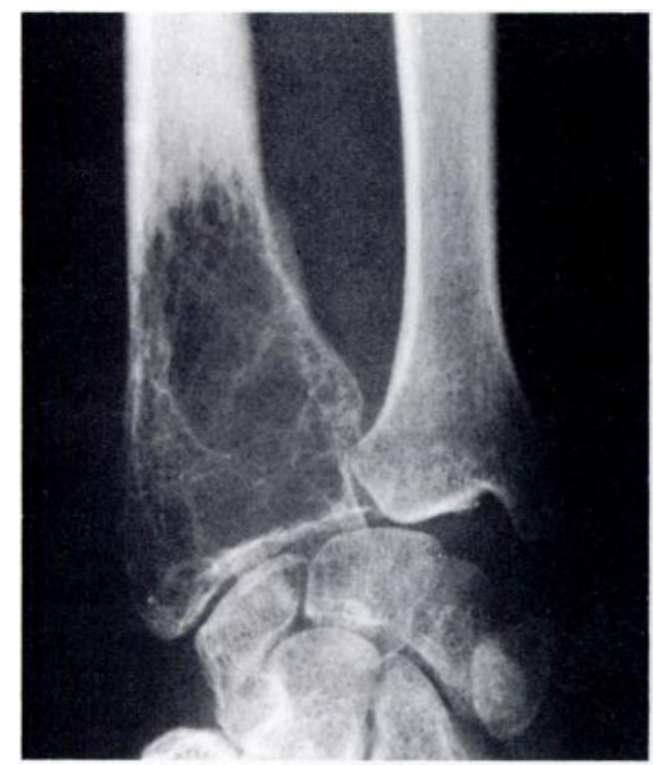

Fig. 3

\section{DISCUSSION}

In each of these patients recurrence appeared to be the result of tumour cells being left in the soft tissue of the bed for the fibular autograft: at the time of revision, tumours were found in the soft tissues with erosion of the adjacent cortex of the fibula in Case 1, and of the scaphoid-fibular arthrodesis in Case 2.

It is surprising to us that recurrence from soft-tissue seeding at the time of massive excision and bone-graft replacement does not occur more commonly. We found one identical case in the literature (Thomas 1952). Goldenberg et al. (1970) reported two recurrences in seven patients after en bloc excision of the distal radius with bone-graft replacement and commented on the possibility of the seeding resulting from transfer on surgical instruments. At the Toronto General Hospital,

Case 2. Figure 3-Radiographic appearance at the time of the original biopsy. Figure 4-Radiograph taken 14 months after the fibular autograft. The scaphoid has been almost completely replaced by a cyst.

One year later a soft-tissue mass one centimetre in diameter was noted over the anatomical snuff box. Within two months, two additional soft-tissue masses were noted more proximally in the scar. Radiographs showed a cystic lesion in the carpal scaphoid where it had been fused to the fibula (Fig. 4).

At operation the soft-tissue nodules were excised. The scaphoid was found to be almost entirely replaced by brown, soft tissue which was curetted away. A bone graft was not necessary as the fibular graft was solidly fused to the rest of the carpus. The histological report of this material, as well as that of the en bloc excision, was "giant-cell tumour (Grade II), similar in appearance to previous material". Subsequently, the patient received 3500 rads of radiation in 15 fractions. He was last seen six years after the initial operation; he remained free of recurrence and had a solid fusion of the wrist. we have had one patient in whom seeding of the iliac crest donor site occurred when the graft had been taken with the same instruments as those used to curette the tumour (Joynt and Ortved 1948).

It is clear that cells of giant-cell tumours can survive in soft tissue and later invade bone (Riley, Hartmann and Robinson 1967). Autograft replacement for giantcell tumours is increasingly popular and is successful (Smith and Mankin 1977); our experience, and similar reports in the literature, emphasises the importance of radical en bloc excision of the primary lesion. Campbell and Akbarnia (1975) point out that the resection must be extraperiosteal and that soft-tissue invasion by tumour and adjacent structures adherent to the tumour must be removed.

The recurrence in our patients, and in similar ones reported, occurred at a time when the autograft could not 
have been completely replaced by new bone and was still partially necrotic. Whether or not this makes the autograft more prone to invasion from soft-tissue seeding is unknown. The current trend of using vascularised autografts and allografts may eventually provide the answer (Smith and Mankin 1979; Pho 1981).

\section{REFERENCES}

Campbell CJ, Akbamia BA. Giant-cell tumor of the radius treated by massive resection and tibial bone graft. J Bone Joint Surg [Am] 1975; 57-A:982-6.

Goldenberg RR, Campbell CJ, Bonfiglio M. Giant-cell tumor of bone. J Bone Joint Surg [ Am] 1970;52-A :619-63.

Joynt GHC, Ortved WE. The accidental operative transplantation of benign giant cell tumor. Ann Surg 1948;127:1232-9.

Pho RWH. Malignant giant-cell tumor of the distal end of the radius treated by a free vascularized fibular transplant. J Bone Joint Surg [Am] $1981 ; 63-A: 877-84$.

Riley LH, Hartmann WH, Robinson RA. Soft-tissue recurrence of giant-cell tumor of bone after irradiation and excision. J Bone Joint Surg [ Am] 1967:49-A:365-8.

Smith RJ, Mankin HJ. Allograft replacement of distal radius for giant cell tumor. J Hand Surg 1977;2:299-309.

Thomas. Osteoclastoma of radius. J Bone Joint Surg [Br] 1952;34-B:524-5. 